\title{
Carbon Dots from Turnip Juice: Synthesis, Characterization and Investigation of pH-Dependent Optical Properties
}

\section{Şalgam Suyundan Karbon Noktalar: Sentezi, Karakterizasyonu ve pH-Bağımlı Optic Özelliklerinin İncelenmesi}

Geliş / Received: 05/08/2021

\author{
Mustafa Çeşme ${ }^{1}$, Hasan Eskalen ${ }^{2 *}$
}

Revize / Revised: 23/09/2021

Kabul / Accepted: 27/09/2021

\begin{abstract}
In this study, carbon dots (CDs) were synthesized using a simple one-pot hydrothermal method by using turnip juice as carbon source. The water-soluble nontoxic carbon dots were obtained after reaction. The structural and optical properties of as synthesized CDs were elucidated by X-ray diffraction (XRD), Raman, Fourier Transmission Infrared (FTIR), UV-Vis absorption and Photoluminescence (PL) spectroscopy. A contour plot of the excitation dependent PL spectra of the turnip juice derived CDs and PL emission spectra in 3D color map were plotted. The maximum PL emission was found at $434 \mathrm{~nm}$ when excited at 364 . The $\mathrm{pH}$ dependent luminescence properties of the CDs were investigated from $\mathrm{pH}$ 2-12 range in phosphate buffer solution (PBS). The resulting CDs can be evaluated in a variety of application areas, from anti-counterfeiting to bioimaging.
\end{abstract}

Keywords- Carbon Dots, Turnip Juice, Ph Dependent Photoluminescence

\section{$\overline{\mathbf{O Z Z}}$}

Bu çalışmada, karbon kaynağı olarak şalgam suyu kullanılarak basit ve tek aşamalı hidrotermal sentez yöntemi ile karbon noktalar (KN'lar) sentezlenmiştir. Reaksiyon sonrasında suda çözülebilen ve toksit olmayan karbon noktalar elde edilmiştir. Sentezlenen KN'ların yapısal karakterizasyonu ve optik özellikleri, X-ışını kırınımı (XRD), Raman, Fourier Dönüşümlü Kızılötesi spektroskopisi (FTIR), UV-Vis ve Fotolüminesans (FL) spektroskopisi ile aydınlatılmıştır. Şalgam suyundan elde edilen KN'ların FL spektrumlarının düzey çizgili grafiği ve 3D renkli harita yüzey görüntüsü çizildi. Maksimum FL emisyonu, 364 nm'de uyarıldığında, 434 nm'de bulunmuştur. CD'lerin pH'a bağlı lüminesans özellikleri, fosfat tampon çözeltisi kullanılarak pH 2-12 aralığından araştırılmıştır. Ortaya çıkan CD'ler, sahteciliğe karşı korumadan biyogörüntülemeye kadar çeşitli uygulama alanlarında değerlendirilebilir.

\section{Anahtar Kelimeler- Karbon Noktalar, Şalgam Suyu, Ph Bă̆ımlı Fotolüminesans}

1İletişim: mustafacesme@msn.com (https://orcid.org/0000-0002-2020-5965)

Kimya Bölümü, Fen Edebiyat Fakültesi, Kahramanmaraş Sütçü İmam Üniversitesi, Kahramanmaraş, Türkiye.

${ }^{2 *}$ Sorumlu yazar iletișim: eskalen@ksu.edu.tr (https://orcid.org/0000-0002-4523-6573)

Malzeme Bilimi ve Mühendisliği, Kahramanmaraș Sütçü Imam Üniversitesi, Kahramanmaraș, Türkiye. 


\begin{tabular}{l|lr}
\hline \hline & $\begin{array}{l}\text { BŞEÜ Fen Bilimleri Dergisi } \\
8(2), 924-930,2021\end{array}$ & $\begin{array}{r}\text { BSEU Journal of Science } \\
\text { BiLECIKEYY EDEBAL } \\
\text { UN IVER SITESI }\end{array}$ \\
\hline
\end{tabular}

\section{INTRODUCTION}

Carbon dots (CDs) are a special member of an important carbon nanomaterial family that has attracted attention in recent years. CDs are known as quasi-spherical particles with sizes below $10 \mathrm{~nm}$. Studies on CDs are increasing day by day, and the application areas of carbon dots are expanding accordingly. These special nanoparticles have a place in many different application fields, such as bio-imaging, optical sensor, catalysis and solar cells because of unique photoluminescence (PL) properties, water solubility, chemical stability and low cost $[1,2]$. The most of the interest is given to PL properties of CDs, and they can exhibit both excitation dependent and excitation independent PL behaviour. Compared to quantum dots, CDs are superior in terms of non-toxic nature, synthesize procedure and synthesize cost; because of this reason, CDs are also considered as potential alternative to quantum dots $[3,4]$.

The synthesis of CDs is divided into two categories namely top-down and bottom up [5]. At the top-down category, bulk carbon nanomaterials converted to tiny pieces. Laser ablation, arc discharge, electrochemical oxidation method are common example of this approach [6-8]. At the bottom up approach, carbon dots derived from small organic molecular precursors. Hydrothermal treatment, pyrolytic process, plasma treatment, microwave synthesis [9], chemical oxidation, and thermal decomposition are some common methods in this approach $[10,11]$. In bottom up approach, carbon dots can obtained from every carbonic material which can burn under suitable condition [12]. Finally, this method offer some advantages regarding to large scale CDs production and synthesis cost [3].

In the different application areas of CDs sensitivity, $\mathrm{pH}$ is very important. For instance, intracellular $\mathrm{pH}$ is important for the functions of organelles and metabolism of the cells [8]. In literature, $\mathrm{pH}$ dependent PL properties of CDs have been examined by different works. The linear relationship of PL intensity of the ascorbic acid derived CDs between pH 4 to $\mathrm{pH} 8$ was found b Jia et al. [13]. Ghanem et al, synthesized N-doped CDs and investigate $\mathrm{pH}$ dependent PL properties of the CDs. A linear relationship of $\mathrm{pH}$ dependent PL values between $\mathrm{pH}$ 1 to $\mathrm{pH} 7$ was obtained [14]. The PL intensity of CDs from $\mathrm{pH} 2$ to $\mathrm{pH} 12$ was investigated and possibility of optical pH sensors was discussed by Zhang et al [15]. The PL peak position slightly change between $\mathrm{pH} 2$ to $\mathrm{pH}$ 6 and from $\mathrm{pH} 7$ to $\mathrm{pH} 12$ redshift of PL peak position from $458 \mathrm{~nm}$ to $491 \mathrm{~nm}$ was found at the mentioned study. To sum up, $\mathrm{pH}$ dependent PL properties of the CDs discussed in previous studies but the of linear $\mathrm{pH}$ ranges is need to investigate more. Since the synthesis of CDs that PL behaviour shows long rang linear response to $\mathrm{pH}$ is important for optical sensors.

Turnip juice is known as traditional Turkish beverage. It contains black carrots, bulgur flour, turnip, Baker's yeast and rock salt. This beverage is purplish-red color due to black carrot content [16]. It is produced by lactic acid fermentation. Generally this beverage manufactured in Adana, Mersin, Kahramanmaraş, Gaziantep, Osmaniye and Hatay provinces in Turkey [17]. In this study, turnip juice was chosen as a carbon source due to its rich components, such as $\beta$-carotene, group B vitamins, calcium, potassium, and iron [18]. The present study, to best of our knowledge for the first-time turnip juice was used to synthesis CDs by hydrothermal method. The synthesized CDs were characterized and $\mathrm{pH}$-dependent optical properties were investigated.

\section{MATERIALS AND METHODS}

\section{A. Synthesis of the C-Dots}

The CDs were synthesized by a simple, one-pot and fast hydrothermal method. Turnip juice was obtained from local market. Shortly, $50 \mathrm{ml}$ turnip juice was placed into teflon-lined stainless steel autclave for $10 \mathrm{~h}$ at 180 ${ }^{\circ} \mathrm{C}$. After the carbonization process, the product was cooled to room temperature naturally, and the brownish solution product was filtered. After that, the filtered solution mixture placed in the falcon tubes was centrifuged at $15000 \mathrm{rpm}$ for 20 minutes to allow the large particles to settle to the bottom. The obtained CD samples were kept in the fridge at $4{ }^{\circ} \mathrm{C}$ for experimentation and characterization processes that would be carried out in later stages.

\section{B. Apparatus and Reagents}

Optical properties of the sythesized CDs were examined by using UV-Vis absorption spectra (Shimadzu1800 UV-Vis spectrometer) and Photoluminescence (PL) spectrum (Varian Cary Eclipse spectrometer) respectively. The excitation/emission slit width was adjusted as $5 / 20 \mathrm{~nm}$. Crysatlline pattern of CDs were measured by XRD instrument with Philips X'Pert PRO XRD with $\mathrm{Cu} K \alpha$ radiation $(\lambda=0.154056 \mathrm{~nm}$, set at $40 \mathrm{kV}$ and 30 
mA). Raman spectrum of synthesized CDs was explored with a portable Raman spectrometer BWS465 B\&W Tek Inc (an excitation wavelength of $785 \mathrm{~nm}$ ). Fourier Transmission Infrared spectroscopy (FTIR) was examined out on a Perkin Elmer Spectrum 400 with a universal demountable cell mount for liquid samples in the range of 4000 to $400 \mathrm{~cm}^{-1}$. The $\mathrm{pH}$ meters Thermo Scientific A215 were used for the $\mathrm{pH}$ measurements. Dynamica Velocity centrifuge was used to separete larger carbon nanoparticles. All chemicals were of analytical grade, and fresh distilled and deionized water was used to prepare all solutions.

\section{RESULTS AND DISCUSSION}

The X-ray diffractograms of the synthesized CDs is demonstrated in Figure 1. There is broad diffraction peak at $24.01^{\circ}$ that is corresponding to graphitic structure. Moreover, the wide diffraction peak is attributed to small size of synthesized CDs [15]. This apparent peak corresponds to (002) plane and the interlayer spacing was calculated as $0.37 \mathrm{~nm}$. The wide diffraction peak also related to amorphous nature of synthesized carbon dots $[19,20]$. Raman spectrum was also measured to underline structural properties of the CDs and it is given in Figure 2. The two clear peak at 1344 and $1538 \mathrm{~cm}^{-1}$ in the spectrum is shown that is attributed to D-band ( $\mathrm{sp}^{3}$ defects) and G-band ( $\mathrm{sp}^{2}$ clusters) respectively $[21,22]$.

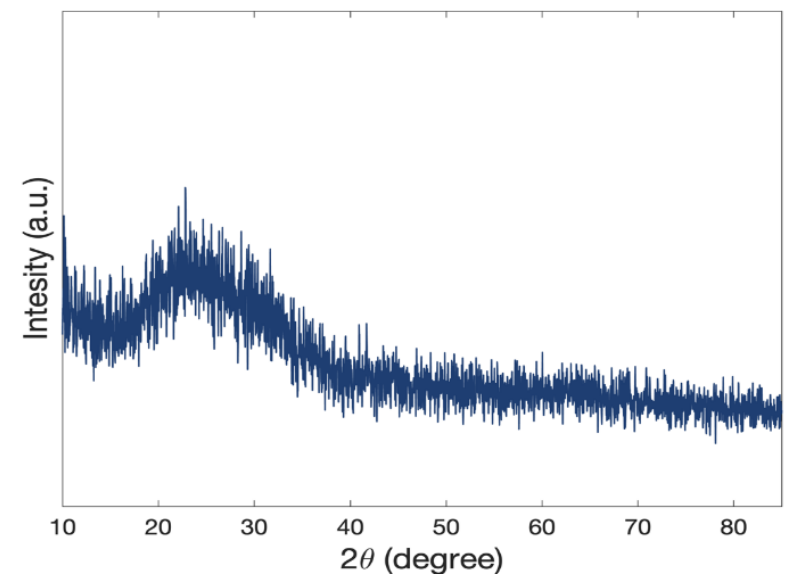

Figure 1. XRD pattern of the synthesized CDs.

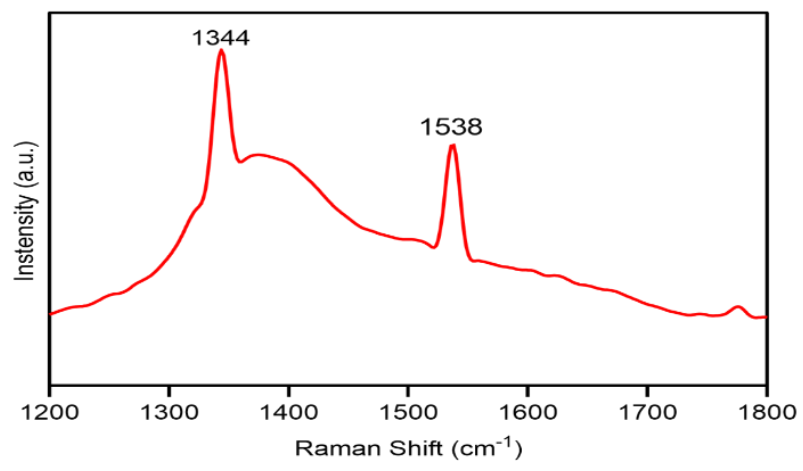

Figure 2. Raman spectrum of the prepared CDs.

The UV-Vis spectrum of turnip juice derived carbon dots is demonstrated in Figure 3. As shown in this figure, the synthesized CDs gives a strong absorption peak at $280 \mathrm{~nm}$ which is attributed to $\pi-\pi^{*}$ transition of the $\mathrm{C}=\mathrm{C}$ bonds of the aromatic rings [23]. Also the long tail to $600 \mathrm{~nm}$ indicate to occurrence of CDs [24]. Infrared spectroscopy of carbon dots was taken to further prove the presence of important functional groups in the structure of the CDs. As seen in Figure 4, infrared spectrum of turnip $\mathrm{CDs}$, $\mathrm{O}-\mathrm{H}$ vibration stretching and $\mathrm{C}=\mathrm{O}$ vibration stretching peaks were observed, respectively, at 3438 and $1636 \mathrm{~cm}^{-1}$. There is a small peak between these two main CDs peaks which shown in $2183 \mathrm{~cm}^{-1}$ is attributed $\mathrm{C} \equiv \mathrm{C}$ vibration stretching [7]. In the light of this spectrum of $\mathrm{CDs}$, the existence of these functional groups, such as $-\mathrm{OH},-\mathrm{COOH}$ and benzene ring can be evaluated in advance. These two stretching peaks are particularly important evidence of the presence of the $\mathrm{sp}^{2}$ hybrid honeycomb cage in the structure of the CDs [25]. 


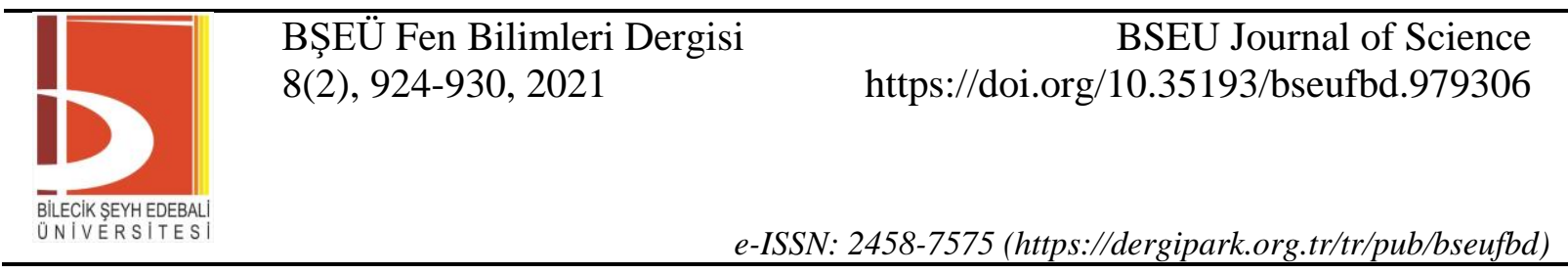

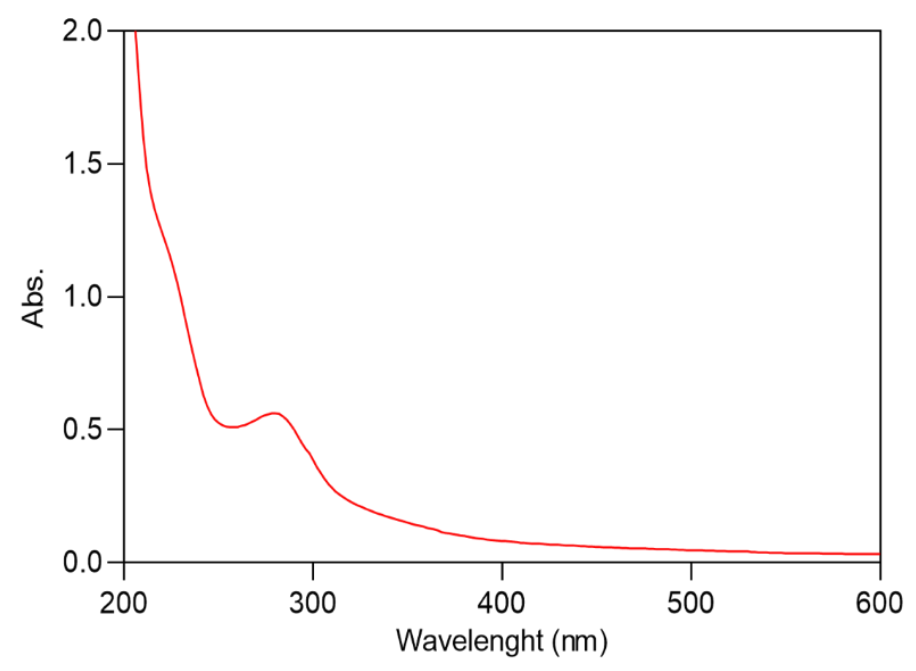

Figure 3. UV-Vis spectrum of the turnip juice derived CDs.

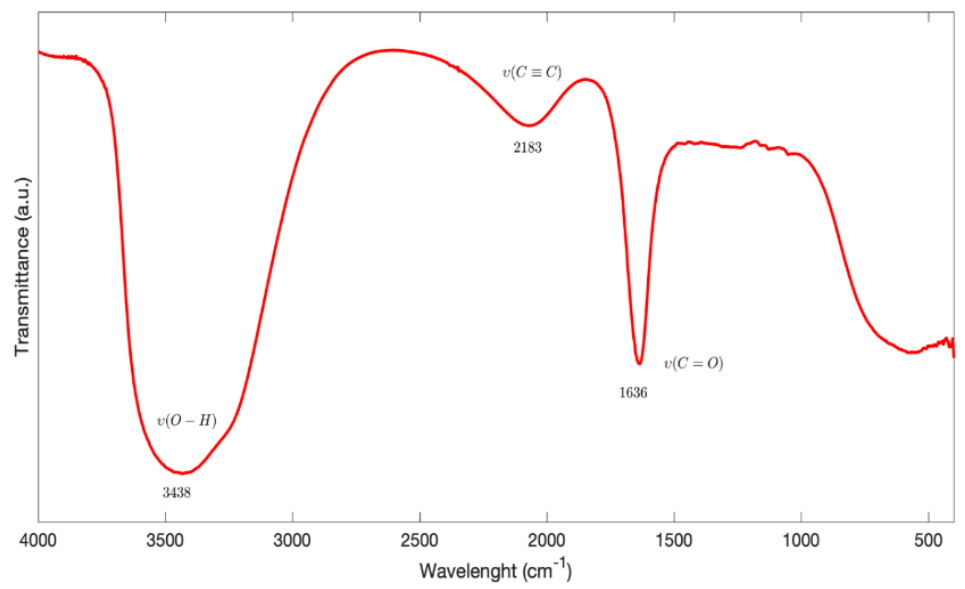

Figure 4. FTIR spectrum of the synthesized CDs.

The excitation dependent photoluminescence (PL) properties of the hydrothermally synthesized CDs is illustrated in Figure 5. As the excitation wavelength increase, the intensity of emission peak also increases and reached the maximum value of $434 \mathrm{~nm}$ when excited at $364 \mathrm{~nm}$, but after this point, emission peak decreases in the PL intensity. The excitation wavelength were ranging from $336 \mathrm{~nm}$ to $436 \mathrm{~nm}$, and the redshift in the emission intensity were found with increasing excitation wavelength and after emission peak stats to decrease after certain point that is refer to common feature of the formation of CDs [26]. The existences of different surface active states on CD might the reason of excitation dependent PL properties of the synthesized CDs [23,27]. 


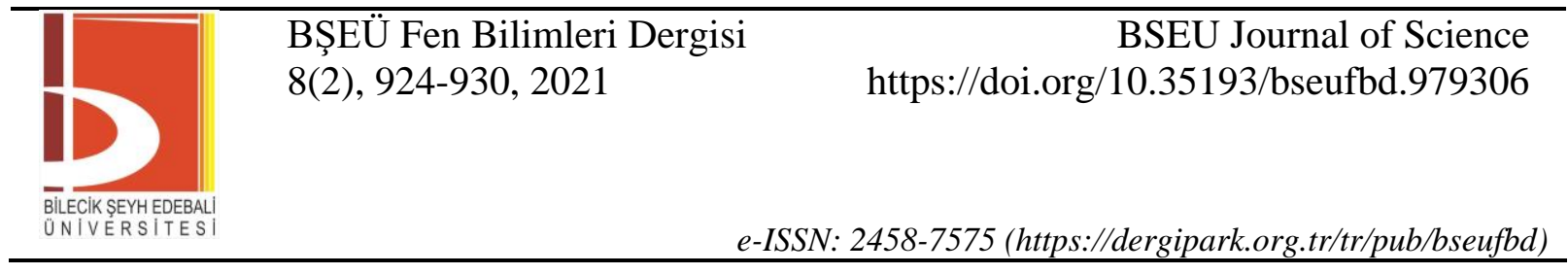

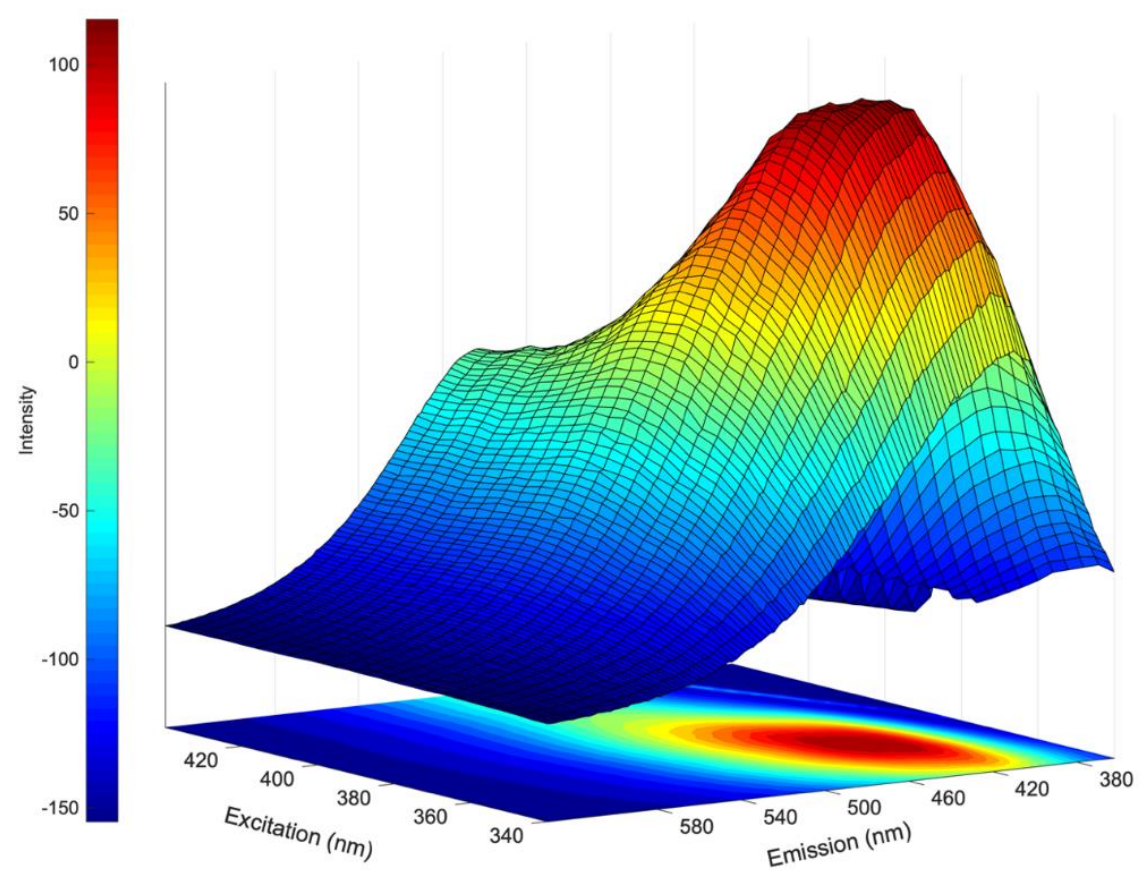

Figure 5. A contour plot of the excitation dependent PL spectra of the turnip juice derived CDs and 3D PL excitation emission map.
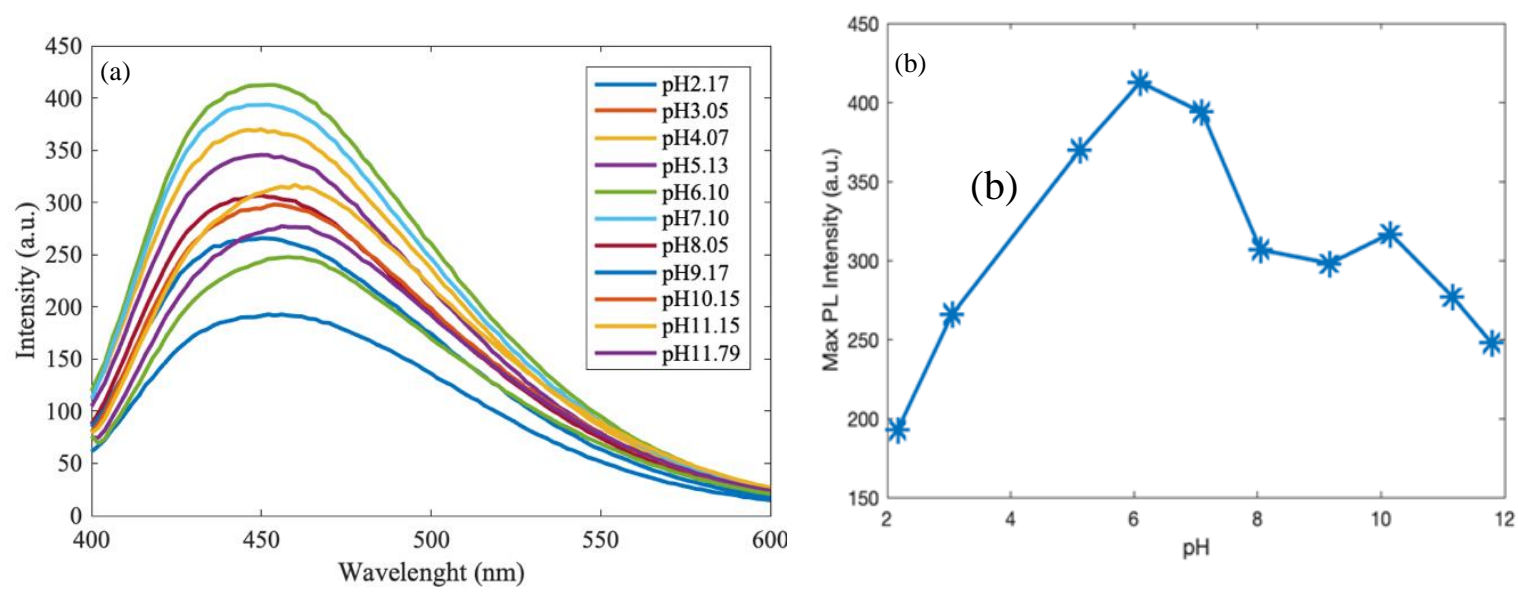

Figure 6. (a) The turnip juice derived $\mathrm{CDs} \mathrm{pH}$ dependent $\mathrm{P}$ emission spectra, (b) The maximum emission peak versus pH values.

It is important to examine the relationship of fluorescence behaviour of carbon dots with $\mathrm{pH}$ change. Accordingly, since the $\mathrm{pH}$ stability in carbon dots applications can directly affect the spectral properties of carbon dots, it is worth researching how it will change in acidic, basic, and neutral media. In this context, the impact of $\mathrm{pH}$ values on PL emission intensity of turnip juice derived carbon dots was investigated. The prepared carbon dots were dispersed in pure water. The $\mathrm{pH}$ measurements were taken with phosphate buffer solution (PBS) within $\mathrm{pH}$ range of 2 to 12 and the spectra were demonstrated in Figure 6 (a) and (b). Figure 6 (a) illustrate the emission spectra of the CDs as a function of $\mathrm{pH}$ at $364_{\mathrm{ex}}$. As seen from the Figure 6 (b), the behaviour of $\mathrm{pH}$ dependent $\mathrm{PL}$ may be investigated in four main regions. Firstly, in acidic medium; the emission intensity was gradually increased from $\mathrm{pH} 2$ to $\mathrm{pH}$ 6. The max PL intensity of turnip juice derived CDs was found at $\mathrm{pH} 6$. At the second region, from the pH 6 to 8 the intensity of PL peak sharply decreased. This may be due to protonation or deprotonation of groups, such as $\mathrm{C}=\mathrm{O}, \mathrm{OH},-\mathrm{COOH}$ on $\mathrm{CDs}$ surface in acidic and basic environments [26]. However, as the media more basic (from $\mathrm{pH} 8$-to 10) the PL intensity mostly stable (third region). At the last region, PL intensity also decreases with the increase of basicity. 


\section{CONCLUSION}

Herein we report, turnip juice derived carbon dots by hydrothermal method without any chemical regents. The as prepared CDs were characterized by several analytical and instrumental techniques, such as XRD, FTIR, Raman, Uv-vis, PL spectroscopy. The XRD results revealed that the synthesized CDs were amorphous nature. The maximum emission of CDs was found at $434 \mathrm{~nm}$ when excited at $364 \mathrm{~nm}$. The $\mathrm{pH}$ dependent luminescence properties of the $\mathrm{CDs}$ were investigated wide $\mathrm{pH}$ range in PBS. According $\mathrm{pH}$ dependent $\mathrm{PL}$ results, the maximum intensity of luminescence peak was strongly related to $\mathrm{pH}$ values of media. The main reason of this phenomena protonation or deprotonation of groups, such as $\mathrm{C}=\mathrm{O}, \mathrm{OH},-\mathrm{COOH}$ on $\mathrm{CDs}$ surface in acidic and basic environments. The prepared CDs would be used in different application areas.

\section{ACKNOWLEDGMENTS}

This work was financially supported by the Kahramanmaraş Sütçü İmam University Scientific Research Projects Coordination Unit (Project Number: 2019/5-21 M and 2021/1-7 YLS).

\section{REFERENCES}

[1] Chen, T., Lin, Y., Li, H., Yang, R., Hou, X., Zheng, B., \& Zheng, C. (2020). Reduction of mercury(II) by electrons contained in carbon dots: An environmentally friendly cold vapor generation for mercury analysis. Chinese Chemical Letters. https://doi.org/https://doi.org/10.1016/j.cclet.2020.06.005

[2] Dinç, S. \& Kara, M. (2018). Synthesis and Applications of Carbon Dots from Food and Natural Products: A Mini- Review. Journal of Apitherapy and Nature, 1(1), 33-37.

[3] Zhang, J., \& Yu, S. H. (2016). Carbon dots: large-scale synthesis, sensing and bioimaging. Materials Today, 19(7), 382-393. https://doi.org/10.1016/j.mattod.2015.11.008

[4] Eskalen, H. (2020). Influence of carbon quantum dots on electro-optical performance of nematic liquid crystal. Applied Physics A, 126(9), 708. https://doi.org/10.1007/s00339-020-03906-7

[5] Singh, I., Arora, R., Dhiman, H., \& Pahwa, R. (2018). Carbon quantum dots: Synthesis, characterization and biomedical applications. Turkish Journal of Pharmaceutical Sciences, 15(2), 219-230. https://doi.org/10.4274/tjps.63497

[6] Zuo, P., Lu, X., Sun, Z., Guo, Y., \& He, H. (2016). A review on syntheses, properties, characterization and bioanalytical applications of fluorescent carbon dots. Microchimica Acta, 183(2), 519-542. https://doi.org/10.1007/s00604-015-1705-3

[7] Boobalan, T., Sethupathi, M., Sengottuvelan, N., Kumar, P., Balaji, P., Gulyás, B., ... \& Arun, A. (2020). Mushroom-Derived Carbon Dots for Toxic Metal Ion Detection and as Antibacterial and Anticancer Agents. ACS Applied Nano Materials, 3(6), 5910-5919. https://doi.org/10.1021/acsanm.0c01058

[8] Shi, W., Li, X., \& Ma, H. (2012). A Tunable Ratiometric pH Sensor Based on Carbon Nanodots for the Quantitative Measurement of the Intracellular pH of Whole Cells. Angewandte Chemie, 124(26), 6538-6541. https://doi.org/10.1002/ange.201202533

[9] Wang, Q., Liu, X., Zhang, L., \& Lv, Y. (2012). Microwave-assisted synthesis of carbon nanodots through an eggshell membrane and their fluorescent application. Analyst, 137(22), 5392-5397. https://doi.org/10.1039/C2AN36059D

[10] Ghosal, K., \& Ghosh, A. (2019). Carbon dots: The next generation platform for biomedical applications. Materials Science and Engineering C, 96, 887-903. https://doi.org/10.1016/j.msec.2018.11.060

[11] Aslan, M., \& Eskalen, H. (2021). A study of carbon nanodots (carbon quantum dots) synthesized from tangerine juice using one-step hydrothermal method. Fullerenes, Nanotubes and Carbon Nanostructures, 18. https://doi.org/10.1080/1536383X.2021.1926452

[12] Hola, K., Zhang, Y., Wang, Y., Giannelis, E. P., Zboril, R., \& Rogach, A. L. (2014). Carbon dots-Emerging light emitters for bioimaging, cancer therapy and optoelectronics. Nano Today, 9(5), 590-603. https://doi.org/https://doi.org/10.1016/j.nantod.2014.09.004

[13] Jia, X., Li, J., \& Wang, E. (2012). One-pot green synthesis of optically pH-sensitive carbon dots with upconversion luminescence. Nanoscale, 4(18), 5572-5575. https://doi.org/10.1039/c2nr31319g

[14] Ghanem, A., Al-Qassar Bani Al-Marjeh, R., \& Atassi, Y. (2020). Novel nitrogen-doped carbon dots prepared under microwave-irradiation for highly sensitive detection of mercury ions. Heliyon, 6(4), e03750. https://doi.org/10.1016/j.heliyon.2020.e03750

[15] Zhang, C., Cui, Y., Song, L., Liu, X., \& Hu, Z. (2016). Microwave assisted one-pot synthesis of graphene quantum dots as highly sensitive fluorescent probes for detection of iron ions and $\mathrm{pH}$ value. Talanta, 150, 54-60. https://doi.org/10.1016/j.talanta.2015.12.015 
[16] Karaoglan, H. A., Keklik, N. M., \& Develi Isıklı, N. (2019). Degradation kinetics of anthocyanin and physicochemical changes in fermented turnip juice exposed to pulsed UV light. Journal of Food Science and Technology, 56(1), 30-39. https://doi.org/10.1007/s13197-018-3434-1

[17] Tulun, Ş., Şimşek, İ., Bahadır, T., \& Çelebi, H. (2019). Investigation of removal of anthocyanin in turnip juice wastewater by using different adsorbents. SN Applied Sciences, 1(9), 967. https://doi.org/10.1007/s42452-019-1019-x

[18] Coskun, F. (2017). A Traditional Turkish Fermented Non-Alcoholic Beverage, "Shalgam.” Beverages, 3(4), 49. https://doi.org/10.3390/beverages3040049

[19] Eskalen, H., Uruş, S., Cömertpay, S., Kurt, A. H., \& Özgan, Ş. (2020). Microwave-assisted ultra-fast synthesis of carbon quantum dots from linter: Fluorescence cancer imaging and human cell growth inhibition properties. Industrial Crops and Products, 147, 112209.

[20] Eskalen, H. (2020). Influence of carbon quantum dots on electro-optical performance of nematic liquid crystal. Applied Physics A, 126(9), 1-10.

[21] Zulfajri, M., Rasool, A., \& Huang, G. G. (2020). A fluorescent sensor based on oyster mushroom-carbon dots for sensing nitroarenes in aqueous solutions. New Journal of Chemistry, 44(25), 10525-10535. https://doi.org/10.1039/D0NJ02134B

[22] Atchudan, R., Edison, T. N. J. I., Perumal, S., Muthuchamy, N., \& Lee, Y. R. (2020). Hydrophilic nitrogendoped carbon dots from biowaste using dwarf banana peel for environmental and biological applications. Fuel, 275, 117821. https://doi.org/10.1016/j.fuel.2020.117821

[23] Murugan, N., \& Sundramoorthy, A. K. (2018). Green synthesis of fluorescent carbon dots from Borassus flabellifer flowers for label-free highly selective and sensitive detection of Fe3+ ions. New Journal of Chemistry, 42(16), 13297-13307. https://doi.org/10.1039/c8nj01894d

[24] Sinha, R., Bidkar, A. P., Rajasekhar, R., Ghosh, S. S., \& Mandal, T. K. (2020). A facile synthesis of nontoxic luminescent carbon dots for detection of chromium and iron in real water sample and bio- imaging. The Canadian Journal of Chemical Engineering, 98(1), 194-204. https://doi.org/10.1002/cjce.23630

[25] Wang, Y., Man, Y., Li, S., Wu, S., Zhao, X., Xie, F., ... \& Zou, W. S. (2020). Pesticide-derived bright chlorine-doped carbon dots for selective determination and intracellular imaging of Fe(III). Spectrochimica Acta - Part A: Molecular and Biomolecular Spectroscopy, 226, 117594.

[26] Zhang, H., You, J., Wang, J., Dong, X., Guan, R., \& Cao, D. (2020). Highly luminescent carbon dots as temperature sensors and "off-on" sensing of $\mathrm{Hg} 2+$ and biothiols. Dyes and Pigments, 173, 107950. https://doi.org/10.1016/j.dyepig.2019.107950

[27] Çeşme, M., \& Eskalen, H. (2020). Green synthesis of carbon quantum dots from sumac: characterization and investigation with cyclic voltammetry technique. Cumhuriyet Science Journal, 41(4), 808-814. 